\title{
A REVIEW ON BIOREMEDIATION OF PETROLEUM HYDROCARBON CONTAMINANTS IN SOIL
}

\author{
${ }^{1}$ Bijay Thapa*, ${ }^{1}$ Ajay Kumar KC, ${ }^{2}$ Anish Ghimire \\ ${ }^{1}$ M.Tech in Environmental Engineering, Civil Eng. Dept., \\ National Institute of Technology-Kurukshetra, Haryana 136119, India \\ ${ }^{2}$ M.E. in Environmental Engineering and Management \\ School of Environment, Resources and Development, Asian Institute of Technology, \\ Pathumthani 12120, Bangkok, Thailand \\ *Corresponding address: thapabijay88@ hotmail.com \\ Received 31 October, 2011; Revised 29 January, 2012
}

\begin{abstract}
This review article illustrates the pros and cons of using bioremediation process for the remediation of petroleum contaminants in soil. Bioremediation along with other processes have been used to remediate petroleum hydrocarbon contaminants in soil in past. The major constituents of most crude oils are biodegradable, so bioremediation has proven to be cheap and efficient than others techniques. Different organisms are employed using various technique of bioremediation according to hydrocarbon present in the contaminated soil. Bioremediation is simpler, less labor intensive and public attitude toward bioremediation are generally favorable, the lack of knowledge about microorganisms and their natural role in the environment could affect the acceptability of their use. However, bioremediation can be considered one of the best technologies to deal with petroleum product contaminated soil.
\end{abstract}

\section{INTRODUCTION}

Most organic chemicals and many inorganic ones are subject to enzymatic attack through the activities of living organisms. Most of modern society's environmental pollutants are included among these chemicals, and the actions of enzymes on them are usually lumped under the term biodegradation. The productive use of biodegradative processes to remove or detoxify pollutants that have found their way into the environment and threaten public health, usually as contaminants of soil, water, or sediments is bioremediation.

Soil contamination with oil spills is the major global concern today. Soil contaminated with Petroleum has a serious hazard to human health [1], causes organic pollution of ground water which limits its use, causes economic loss, environmental problems, and decreases the agricultural productivity of the soil [2]. The concern stems primarily from health risks, from direct contact with the contaminated soil, vapors from the contaminants, and from secondary contamination of water supplies within and underlying the soil. The toxicity of petroleum hydrocarbons to microorganisms, plants, animals and humans is well established. The toxic effects of hydrocarbons on terrestrial higher plants and their use as weedkillers have been ascribed to the oil dissolving the lipid portion of the cytoplasmic membrane, thus allowing cell contents to escape (Currier \& Peoples, 1954, as cited in [3]). The most noticeable sources of contamination are releases from manufacturing and refining installations, oil-tanker spills and accidents during transportation of the oil. Crude oils are transported long distance either on land pipeline or on water in tankers and both of which are prone to oil spill and accidents [3]. A great part of the oil pollution problem results from the fact that the major oil-producing countries are not the major oil consumers. It follows that massive movements of petroleum have to be made from areas of high production to those of high consumption. 
It has been known for 80 years that certain microorganisms are able to degrade petroleum hydrocarbons and use them as a sole source of carbon and energy for growth. The early work was summarized by Davis in 1967. Remediation of the contaminated soil can be done in many ways which include both physico-chemical and biological methods. Biological methods are more economical and efficient then chemical and physical ones [4]. Large numbers of methods have been developed to increase the degradation rate of petroleum products in soil, as it takes much more time than physical and chemical remediation methods. In comparison to other biological method bioremediation through microorganism is more efficient, but the low solubility and adsorption of high molecular weight hydrocarbons limits their availability to microorganisms [4].

Some types of microorganism are able to degrade petroleum hydrocarbons and use them as source of carbon and energy. The specificity of the degradation process is related to the genetic potential of the particular microorganism to introduce molecular oxygen into hydrocarbon and to generate the intermediates that subsequently enter the general energyyielding metabolic pathway of the cell [5]. Some bacteria are mobile and exhibit a chemotactic response, sensing the contaminant and moving toward it, while other microbes like fungi grow in a filamentous form near the contaminant [6].

\section{PRINCIPLE OF BIOREMEDIATION}

Crude oil is a composite mixture of thousands of different chemical compounds. As the composition of each type of oil is unique, there are different ways to deal with them through microbes and flora. Bioremediation can occur naturally or can be encourage with addition of microbes and fertilizers.

The microbes present in the soil first recognize the oil and its constituent by biosurfactants and bio emulsifiers, and then they attach themselves and use the hydrocarbon present in the petroleum as a source of energy and carbon [10]. The low solubility and adsorption of high molecular weight hydrocarbons limit their availability to microorganisms. The addition of biosurfactants enhances the solubility and removal of these contaminants, improving oil biodegradations rates [4].

The constituents of oil differ distinctly in volatility, volubility, and susceptibility to biodegradation. Some compounds are easily degraded, some resist degradation and some are non-biodegradable [9]. The biodegradation of different petroleum compounds occurs simultaneously but at different rates because different species of microbes preferentially attack different compounds. This leads to the successive disappearance of individual components of petroleum over time [11].

Microorganisms produce enzymes in the presence of carbon sources which are responsible for attacking the hydrocarbon molecules. Many different enzymes and metabolic pathways are involved to degrade a hydrocarbons contained in petroleum. But lack of an appropriate enzyme will either prevents attack or will act as a barrier to complete hydrocarbon degradation [12].

\section{BACTERIA}

Although, many microorganisms are capable of degrading the crude oil present in the soil, it has been found beneficial to employ mix culture opposed to pure cultures in bioremediation as it shows the synergistic interactions [8]. Bacteria for hydrocarbon decomposition are commercially available as freeze dried bacteria, which can be used for bioremediation after 
propagation to a minimum of $2 \times 10^{8} \mathrm{CFU} / \mathrm{ml}$ [1]. Bacterias that can degrade petroleum products are-Pseudomonas, Aeromonas, Moraxella, Beijerinckia, $F$ lavobacteria, chrobacteria, Nocardia ,Corynebacteria,Atinetobacter, Mycobactena, ,Modococci , Streptomyces, Bacilli, Arthrobacter,Aeromonas, Cyanobacteria etc.

\section{NUTRIENT}

Although the microorganisms are present in contaminated soil, they cannot necessarily be there in the numbers required for bioremediation of the site. Their growth and activity must be stimulated. Carbon is the most basic form of nutrient required for living organism. In addition to this, the bacteria also need macronutrient like nitrogen and phosphorous to ensure effective degradation of the oil [13]. The optimum nutrient balance required for hydrocarbon remediation is Carbon: Nitrogen: Phosphorus equals 100:10:4. In general, at least 1 ppm of ammonium nitrogen and $0.4 \mathrm{ppm}$ of orthophosphate needs to be present. Pathways can be influenced by further adjusting volumes of bio-nutrients [14].

In addition to hydrogen, oxygen, and nitrogen it constitutes about $95 \%$ of the weight of cells.

Table 1 Composition of a microbial cell.

\begin{tabular}{|l|l|l|l|}
\hline Element & Percentage & Element & Percentage \\
\hline Carbon & 50 & Sodium & 1 \\
\hline Nitrogen & 14 & Calcium & 0.5 \\
\hline Oxygen & 20 & Magnesium & 0.5 \\
\hline Hydrogen & 8 & Chloride & 0.5 \\
\hline Phosphorous & 3 & Iron & 0.2 \\
\hline Sulfur & 1 & All others & 0.3 \\
\hline Potassium & 1 & & \\
\hline
\end{tabular}

R. Y. Stainer et al. (1986) (as cited in Vidali (2001)).

Phosphorous and sulfur contribute with $70 \%$ of the remainders. The nutritional requirement of carbon to nitrogen ratio is 10:1, and carbon to phosphorous is 30:1.

\section{ELECTRON ACCEPTOR / OXYGEN}

Although oxygen is not the rate limiting factor, it's one of the most essential elements of microbial degradation of hydrocarbons [12]. Oxygen is necessary for the initial breakdown of hydrocarbons and succeeding reaction may require it. In presence of oxygen complete degradation of oil takes place. If large quantities of oil are present, the oxygen in the soil will be depleted very fast causing anaerobic condition.

Anaerobic bacteria will use other electron acceptors like nitrate, iron or sulphate, but the energy yield for the bacteria is less than oxygen used as the electron acceptor [15]. The lower energy yield by anaerobic bacteria results in lower degradation and hence a longer period of time is required for remediation [12].

\section{DETERGENT}

Oils are hydrophobic in nature, their availability to bacteria are limited which leads to the slow degradation. Adding detergent to the oil contaminated soil help in desorbing the hydrocarbon and hence boost up the remediation. Generally microbiologically produced detergents called rhamnolipids are used. They are character by having rhamnose moieties and a fatty acid tail [16]. 


\section{ENVIRONMENTAL REQUIREMENTS}

Optimum environmental conditions for the degradation of contaminants are reported in Table below.

Table 2 Environmental conditions affecting degradation.

\begin{tabular}{|l|l|l|}
\hline Parameters & $\begin{array}{l}\text { Condition required for } \\
\text { microbial activity }\end{array}$ & $\begin{array}{l}\text { Optimum value for an oil } \\
\text { degradation }\end{array}$ \\
\hline Soil moisture & $\begin{array}{l}25-28 \% \text { of water holding } \\
\text { capacity }\end{array}$ & $30-90 \%$ \\
\hline Soil pH & $5.5-8.8$ minimum air-filled & $6.5-8.0$ \\
\hline Oxygen content & $\begin{array}{l}\text { Aerobic, mo\% } \\
\text { pore space of 10\% }\end{array}$ & C:N:P=100:10:1 \\
\hline Nutrient content & N and p for microbial growth & $20-30$ \\
\hline Temperature $\left({ }^{\circ} \mathrm{C}\right)$ & Not too toxic & $\begin{array}{l}\text { Hydrocarbon 5-10\% of dry } \\
\text { weight of soil }\end{array}$ \\
\hline Contaminants & 700 ppm \\
\hline Heavy metals & Total content 2000 ppm & \\
\hline Type of soil & Low clay or silt content & \\
\hline
\end{tabular}

Source: Vidali (2001)

Microbial growth and activity are readily affected by $\mathrm{pH}$, temperature, and moisture. Although microorganisms have been also isolated in extreme conditions, most of them grow optimally over a narrow range, so that it is important to achieve optimal conditions.

If the soil has too much acid it is possible to rinse the $\mathrm{pH}$ by adding lime. Temperature affects biochemical reactions rates, and the rates of many of them double for each $10{ }^{\circ} \mathrm{C}$ rise in temperature. Above a certain temperature, however, the cells die. Plastic covering can be used to enhance solar warming in late spring, summer, and autumn. Available water is essential for all the living organisms, and irrigation is needed to achieve the optimal moisture level. The amount of available oxygen will determine whether the system is aerobic or anaerobic. Hydrocarbons are readily degraded under aerobic conditions, whereas chlorurate compounds are degraded only in anaerobic ones. To increase the oxygen amount in the soil it is possible to till or sparge air. In some cases, hydrogen peroxide or magnesium peroxide can be introduced in the environment. Soil structure controls the effective delivery of air, water, and nutrients. To improve soil structure, materials such as gypsum or organic matter can be applied. Low soil permeability can impede movement of water, nutrients, and oxygen; hence, soils with low permeability may not be appropriate for in situ clean-up techniques.

\section{BIOREMEDIATION STRATEGIES Biostimulation}

Some microorganisms are present in the contaminated site, but for effective remediation, growth of microorganism should be stimulated. Biostimulation is the process of adding nutrient, electron acceptor and oxygen to stimulate existing bacteria involve in bioremediation. This is the process of optimizing the environment condition of the remediation site.

Additives are usually added to the subsurface through injection wells. Subsurface characteristics such as groundwater velocity, hydraulic conductivity of the subsurface, and lithology of the subsurface are important in developing a biostimulation system [7]. The indigenous microorganism present in the soil is responsible for degradation of the pollutant, but biostimulation can be improved by bioaugmentation. 


\section{BIOAUGMENTATION}

Bioaugmentation is the addition of a group of indigenous microbial strains or genetically engineered microbes to treat the contaminated soil. It is effective where native microorganisms are not identified in the soil or do not have the metabolic capability to perform the remediation process.

\section{ANAEROBIC DEGRADATION}

Most of bioremediation method aims in enhancing oxygen supply to contaminated sites assuming that the principal mechanism of hydrocarbon removal is aerobic respiration. But addition of urea and ammonia-based fertilizers sometimes used for oil-spill bioremediation can potentially exert an oxygen demand due to biological ammonia oxidation. On some sites, mass transfer of oxygen may not be sufficient to replenish oxygen consumed by microbial metabolism, though penetration of oil into deeper sediment layers is also likely to be reduced in fine sediments. Under such conditions anaerobic hydrocarbon degradation may be of relevance.

\section{LAND FARMING}

Land farming is a method in which contaminated soil is spread over a prepared bed along with some fertilizers and occasionally rotated. It stimulates the activity of bacteria and enhances the degradation of oil. The criteria for determining proper site location includes: a minimum separation distance of 3 feet between the ground surface and the seasonable high groundwater table and the slope of the land does not exceed $8 \%$ [17].

\section{COMPOSTING}

Composting is a process of piling contaminated soil organic substances such as manure or agricultural wastes. The added organic material supports the development of a rich microbial population and elevates temperature of the pile. Stimulation of microbial growth by added nutrients results in effective biodegradation in a relatively short period of time.

\section{CONCLUSION}

Researches using bioremediation has shown great promise to date. Further researches in this field can result in the development of most efficient and less time consuming technologies. Also, further research is critical to investigate its application beyond the laboratory-scale and to develop the kinetics of degradation. Bioremediation is usually simple and less labor intensive. Also, as per Frazer [18], Bioremediation is the most economical at the required efficiency when the soil to be treated is more. Although public attitudes toward bioremediation are generally favorable, the lack of knowledge about microorganisms and their natural role in the environment could affect the acceptability of their use. Before bioremediation techniques to be used widely, their efficacy and safety will have to be convincingly demonstrated and communicated to the public.

\section{REFERENCE}

[1] Eugris http://www.eugris.info/newsdownloads / Green Remediation/ pdf /D05 AnneLouise Gimsing_Paper.pdf.

[2] J. Wang, ZZ Zhang, YM Su, W He, F He \& HG Song, Phytoremediation of petroleum polluted soil, Petroleum Science, vol.5 (2) (2008) 167. 
[3] Petroleum - water, effects, environmental, disasters, pollutants, United States, history, causes, impact, EPA, soil, chemicals, industrial, liquid, wells, toxic, world, human, power,

[4] http://www.pollutionissues.com/Na-Ph/Petroleum.html, 27-03-2011

[5] VS, Millioli, ELC, Servulo, LGS Sobral \& DD De Carvalho, Bioremediation of crude oil-bearing soil: evaluating the effect of Rhamnolipid addition to soil toxicity and to crude oil biodegradation efficiency, Global NEST Journal, 11 (2) (2009), 181.

[6] E Rosenberg \& EZ Ron, Bioremediation of petroleum contamination, Bioremediation: Principles and Applications, Cambridge University Press, 1996, ISBN 0-521-47041-2.

[7] M. Vidali, Bioremediation. An overview, Pure Appl. Chem., 73(7) (2001) 1163.

[8] Biostimulation - Wikipedia, the free encyclopedia, http://en.wikipedia.org/wiki/ Biostimulation, retrieved on 28 Mar. 2011.

[9] AM Mukred, A A Hamid, A Hamzah \& WMW Yusoff, Development of Three Bacteria Consortium for the Bioremediation of Crude Petroleum-oil in Contaminated Water, OnLine Journal of Biological Sciences, 8 (4) (2008) 73ISSN 1608-4217.

[10] National Research Council, op. cit., footnote 1, p. 17.

[11] ISU Engineering Information Technology

[12] http://home.eng.iastate.edu/ tge/ce421-521/brubaker.pdf, retrieved on 27th Mar. 2011

[13] Atlas, op. cit., footnote 23, p. 212.

[14] U S Congress, Office of Technology Assessment, Bioremediation for Marine Oil Spills- Background Paper, OTA-BP-0-70 (Washington, DC: U.S. Government Printing Office, May 1991).

[15] JF Braddock, ML Ruth \& PH Catterall, Enhancement and inhibition of microbial activity in hydrocarbon-contaminated artic solis: Implications for nutrient-amended bioremediation, Environmental Science and Technology, 31(1997) 2078.

[16] http://www.bioremediate.com/petrochemical.html, retrieved on 28 Mar. 2011

[17] AM Spormann \& F Widdel, Metabolism of alkylbenzenes, alkanes, and other hydrocarbons in anaerobic bacteria., Biodegradation, 11(2000) 85. 
[18] CN Mulligan, Environmental application for biosurfactants, Environmental pollution, 133(2005) 183.

[19] WMD, Agency guidelines for petroleum contaminated soil and debris, Vermont State agency of Natural Resources Waste Management Division, August 1996

[20] Chris Frazar, The Bioremediation and Phytoremediation of Pesticide-contaminated Sites. U.S. Environmental Protection Agency, Office of Solid Waste and Emergency Response Technology Innovation Office, Washington DC. 2000. 